\title{
AN EXPLORATION OF POWER ASYMMETRY IN THE APPAREL INDUSTRY IN THE UK AND TURKEY
}

\section{Introduction}

With rapid developments in supply chains because of globalisation, ICT and product demands, supply chain managers face increasing pressures of global sourcing and off-shoring (Stratton \& Warburton, 2006). Apparel supply chains typically operate across international borders and involve asymmetric power balances (Tokatli, 2006). Meehan \& Wright (2012) have reported that there is a consensus among authors, concerning the dramatic shift in the balance of power, from suppliers to retailers. For example, private label goods, produced exclusively for large retailers, enable buyers to take control of branding from the supplier (Meehan \& Wright, 2012).This may have reduced the competitive advantage of small suppliers (Hines \& McGowan, 2005) as they have little bargaining power in deals with large retailers (Hingley, 2005).

Recent research found that the most evident consequences of a shift in the balance of power is on small suppliers' capability development, because supplier capabilities develop in the way their buyers want. Furthermore, it would be imprudent if capabilities were not reorganized to meet changing network requirements or used in new relationships with new buyers (Johnsen \& Ford, 2006). In dyadic relationships, interaction utilises the capabilities of a company, but may also determine capability development over time (Ford, Hakansson, \& Johanson, 1986). In asymmetrical relationships, suppliers' capabilities may be employed by the customers to gain benefit, and alterations may only be permitted when needed by customers (Johnsen\& Ford, 2002).Therefore, further exploration is needed regarding SME suppliers' capabilities in asymmetric relationships (Johnsen \& Ford, 2006, 2008). 
Hines \& McGowan (2005) identified a lack of research into such relationships and this is compounded due to the lack of attention attributed to power asymmetry in business-tobusiness relationships (Nyaga et al., 2013). This paper seeks to address this gap by focusing on the experiences of SME apparel manufacturers, based in the UK and Turkey, in relationship with retailers. We use the EU categorisation of SME, i.e. firms with less than 250 employees. The term "apparel" is that defined by Hines \& McGowan (2005, p: 522) "The apparel manufacturer will cut the cloth, make it up and trim to a design template specified by the retail organization before finishing (packing, labelling, pricing) and delivering to a retail customer." The exploratory case methodology focuses on apparel industries in the UK and Turkey which answers Ehrgott et al's (2011) call for research that explores country differences and Connelly et al's (2013) call for understanding how supply chains interact across global boundaries.

Since 1996, there have been no trade restrictions or duty payable for any EU trade with Turkey, a major supplier of textiles and clothing (Hague, Oxborrow, \&McAtamney, 2001). Turkey is the world's sixth largest ready to wear and apparel manufacturer, and the tenth largest supplier of textiles, and the leading and second largest supplier of textiles and apparel, respectively, to the European Union (Federations of Indian Chambers of Commerce, 2014). Turkey has become a world leading textile manufacturing hub and is a top 10 exporters of both apparel and textiles (Foreign and Commonwealth Office, 2014). As the world's seventh largest clothing exporter, including to the UK, Turkey has developed key competencies that have enabled strong partnerships with geographically distant buyers but Tokatli \& Kizilgün (2009)have questioned the sustainability of these competencies as a result of asymmetrical power in supply chains.

The UK apparel market is mature and highly concentrated into a few large retailers. Since the 1980s, globalisation has resulted in a declining UK apparel manufacturing sector through 
closures and firms moving off-shore. Remaining businesses have restructured, providing a variety of services including product development, flexible manufacturing and sourcing, in order to maintain the flow of goods into increasingly volatile markets and differentiate themselves from off-shore suppliers (Lowson, 2003).

The paper focuses on specific elements of power asymmetry in the apparel supply chain and supplier capabilities, thus addressing the need for research (Hines \& McGowan, 2005; Hingley, 2005; Hingley, Angel, \& Lindgreen, 2015; Johnsen \& Ford, 2008) on the power structures evident in supply chain relationships and how these operate in practice. The initial section of the paper articulates the key elements of power in supply chains and discusses the relational view of power and supplier capabilities. The exploratory case findings of 20 SMEs are then presented and conclusions based on the impact of power asymmetry and capabilities are developed.

It is evident in the literature that suppliers' capabilities influence relationships and enable suppliers to overcome power asymmetry and maintain relationship symmetry. Therefore, the following research objectives have been designed.

1. To identify the power asymmetry in the buyer/supplier interface in the apparel industry.

2. To understand how SME suppliers' capabilities mitigate against any identified power asymmetry.

3. To evaluate whether there are any differences/similarities between the approaches of apparel SMEs based in the UK and Turkey.

We wished to explore where power asymmetry occurred in dyadic relationships as previous research had not been clear in this regard. The conflicting arguments concerning asymmetry whether it is harmful to the relationship or stabilises the relationship also required further exploration(Hines \& McGowan, 2005; Nyaga et al., 2013).Secondly, it was evident that 
SMEs continued to be involved in relationships with large retailers, dealing with loss and benefit(Hingley, Angel, \& Lindgreen, 2015; Johnsen \& Ford, 2008), and it was this point that directed us to our second objective, how SMEs mitigate asymmetry. The third objective stemmed from the fact that the same industry, with similar markets in the UK and the EU, but in two different country contexts, would provide rich data to help to identify differences and similarities between the suppliers of two countries and their asymmetric customer relationships.

The main findings of the research derived from our first objective, identified asymmetries in relationships, mainly in the areas of financial controls, contractual issues, communication and size. The second objective: creating inter-dependencies in a number of ways was used by the SMEs to mitigate identified asymmetries. The third objective demonstrates the evaluation of differences between UK and Turkish suppliers over four sets of capabilities: employee, technical, managerial and custom. The significant similarities were identified: the suppliers of both countries have developed production and technical capabilities that help suppliers to provide short lead times in production and delivery, and influence the dynamics of their relationships and the collaborative projects they lead. On the other hand, the significant differences are; employment strategies, sourcing approach and risk taking approach, and adaptation of retailers norms, values and ethical compliance.

The theoretical contribution of our research is that it is amongst the first to examine power asymmetry through a capability framework between apparel suppliers and retailers in two countries - the United Kingdom and Turkey. Data collection in both countries yielded some fruitful contrasts. The framework adapted and used in this study is an important tool to examine the interactions between SMEs and Retailers. This capability framework demonstrated a new approach to explore power asymmetry and understand approaches of 
mitigating asymmetry in dyadic relationships. The utilisation of the Framework, has added a further dimension to the work of the Industrial Marketing Purchasing (IMP) school and the interaction approach (e.g. Ford, Hakansson, \& Johanson 1986; Hakansson, \& Snehota, 1998; Gadde, \& Hakansson, 2002)

Our empirical contribution has been directed towards the exploration of the perspective of SMEs in the asymmetric relationships in two geographically and culturally distinct countries. The issues have previously been compounded by the need to overcome difficulties in reaching and convincing SMEs to participate in academic studies. The approach adopted has provided direction for addressing this persistent challenge for researchers in the SME field.

\section{Literature review}

The increasing importance of power as a determining concept in supply chain relationships has recently received much attention from researchers (Nyaga et al., 2013; Pulles et al., 2014; Maglaras, Bourlakis,\& Fotopoulos, 2015;Chicksand, 2015;Hingley, Angel, \& Lindgreen, 2015). For several decades research focussed on understanding the structure and dynamics of power (Benton \&Maloni, 2005; Caniels \& Gelderman, 2007;Cox, Sanderson, \& Watson. 2001;Kumar, 2005). However, power is still an elusive and underdeveloped concept (Ireland \& Webb, 2007) with a narrow scope (Hingley, 2005; Hingley, Angel, \& Lindgreen, 2015).

In inter-organisational studies, the commonly accepted definition of power is Emerson's (1962, p: 32)"the ability of an actor to influence another to act in the manner that they would not have otherwise". Research using Emerson's (1962) definition has predictably focussed on the dynamics of power (Cox, 2004;Hingley, 2005;Lacoste \&Johnsen, 2014), the use of power (Rindt \& Mouzas, 2015;Nyaga, 2013), the origin of power (Meehan \& Wright, 2012) and power measurement (Belaya, Gagalyuk, \& Hanf, 2009). Alternative views of power tend to focus on power in terms of interdependencies on resources and economic terms: payoffs and cost (Belaya, Gagalyuk, \& Hanf, 2009). Although Emerson's (1962) definition offers limited 
vision, newer research in supplier-customer relations has stated that power can also be used to the advantage of suppliers by focusing on the business processes of their customers and creating inter-dependencies, known as countervailing power(Lacoste \&Johnsen, 2014). Thus, in this review we will move onto discuss how suppliers perceive and position themselves in asymmetric relationships with retailers, which have increasing power in the market (Hines \&McGovan, 2005).

The concept of power can be easily observed in supplier-retailer studies because in asymmetric exchange relationships, retailers are the ones holding the power and can set the rules of the game (Hingley, Angel, \& Lindgreen, 2015). A number of researchers have explored power asymmetry in supply chain exchanges (Johnsen\& Ford, 2008; Lee \&Johnsen, 2011;Nyaga et al., 2013; Rindt\&Mouzas, 2015).They find that the powerful partner applies its power in two main areas: the strategic and operational areas of the weaker party, while the weaker party accepts the control of the powerful party in its business activities in both areas (Johnsen\& Ford, 2008). Furthermore, power asymmetry in supplier-buyer relationships affects the weaker party's adaptive and collaborative behaviour and may provide more chance for the powerful party to exploit opportunity from the relationship (Nyaga et al., 2013). Therefore, there is a need to understand power asymmetry in dyadic relationships as it is an inevitable aspect of supply chain relationships (Cox, 2004).

There is no universally agreed view of the negative effects of power asymmetry, but rather a body of literature that sees its positive side (Belaya, Gagalyuk, \& Hanf, 2009).Hingley (2005) argues that asymmetry need not be a barrier to developing relationships. Indeed, the relationship may provide mutual benefits, which override any possible negative effects of the power asymmetry. Weaker organisations demonstrate a degree of tolerance toward asymmetry and in some cases power asymmetry can stabilise relationships (Lawler, Ford, \& Blegen, 1988).Furthermore, power can be employed by the stronger party to manage 
integration, setting goals and resolving conflict with the weaker party (Belaya, Gagalyuk, \& Hanf, 2009).

Understanding the power structures that exist in supply chain relations can help to achieve the strategic management of supply chains and effective operational practices and avoid recommending sub-optimal strategies to supply chain members (Cox, 1999). Power has been broadly investigated in food supply chains (Hingley, 2005; Maglaras, Bourlakis,\& Fotopoulos, 2015) and the retail sector (Hines \& McGowan, 2005;Oxborrow\& Brindley, 2014). In relation to the increasing exertion of power by retailers, this research has provided a rich perspective and understanding of the study of power in apparel supply chain relationships (Oxborrow\& Brindley, 2014).

This is an important research gap as Meehan \& Wright (2012) have reported that there is a consensus among authors concerning the dramatic shift in the balance of power, from suppliers to retailers. For small suppliers, this could affect their competitive advantage (Hines \&McGowan, 2005) as they could be disadvantaged in deals with large retailers (Hingley, 2005). For example, recent research has shown that the move into private label goods, produced exclusively for large retailers, enables retailers to take control of branding from the supplier (Meehan \& Wright, 2012). This should be no surprise as Ritchie \& Brindley (2000) argued that the traditional linear model of supply chains would fundamentally alter, exposing small suppliers to greater risk and involving small suppliers in managing a multitude of relationships.

\subsection{Power Asymmetry and Relationships}

The paper adopts the view that supply chain management and relationship marketing are complementary paradigms. As Mattsson (1997, p.447) argued relationship marketing is embedded in "the traditional marketing channel literature." Similarly, the notion of 
relationships is a common theme within the supply chain literature. Thus, we can see the coming together of differing concepts from various disciplines e.g. customer satisfaction, relationships and partnerships. Globalisation and technology has integrated suppliers, customers, intermediaries and market spaces in new ways. Thus, when discussing supply chains, the concept is now multi-disciplinary and encompasses themes of relationships, networks, channels and partnerships. The paper sees the supply chain as customer centric involving a series of relationships, both upstream and downstream. The principles of supply chain management and relationship marketing both reduce the degree of uncertainty through improved relationships. Whilst relationship marketing maybe directed primarily towards the customer and the marketplace (Gummesson, 1994)

In the IMP school of thought, the distribution of power depends on the interaction pattern, taking place within the context of relationships between firms that are in turn surrounded with networks of other firms (Hakansson \& Waluszewski, 2013). Hakansson \& Snehota (1995) depicted that symmetry is where the equilibrium of resources and capabilities in a relationship are balanced. There is a chance to achieve a balance in relationships where the resources are influenced and capabilities are developed, if both the buyer and seller aspire to a balanced relationship. Thus, power is a concept that is closely related to reciprocal dependence between interacting parties, with their own goals to achieve, but where one party's goal depends upon the other party's actions. Power thus stems from another party's dependence (Emerson, 1962 cited in Gadde \& Hakansson, 2002). Given that in all power/dependence relationships it is necessary to have balance, Emerson (1962) asserted that if any one party attempts to gain more power, then the other party will try to balance that power against its partner. This is an ongoing process. Cook \& Emerson (1978) stated that the long-term effectiveness of power can be seen as a control mechanism. Indeed, they were of the opinion that the powerful party will exploit the weaker party meaning that there is 
imbalanced or asymmetric power in the relationship, resulting in less cooperation and high levels of conflict (Dwyer et al., 1987).

However, the recent shift of power in the retail market shows that, whilst symmetry maybe the ideal position for both parties, this is not the reality (Meehan \& Wright, 2012) because power is a dynamic construct that can shift or change according to the buying or selling strategies of the actors (Lacoste \&Johnsen, 2014). In addition, although shifting power has important consequences for suppliers in industrial relations with buyers, there is still a limited understanding of power shift and how to manage it(Hakansson \& Gadde, 1992;Johnsen \& Ford, 2002).

The buyer relationships that have developed are dominated by large companies with a focus on cost reduction rather than responsiveness, with trust and commitment not easily achieved (Johnsen\& Ford, 2006). Trust and commitment are critical to the development of mutually beneficial relationships (van Hoek, 2000). Johnsen et al. (2006; after Sako, 1998) identify varying levels of trust which emerge as commitment develops. Issues such as interpretation of contractual expectations, personnel changes, weak actor bonds and differing corporate cultures are found to compromise development of commitment and therefore trust. These are all areas that can be applied to the apparel sector and may prove decisive in shaping the relationships that have been developed and the sustainability of the sector. The apparel sector illustrates some innovative ways of providing responsiveness, in spite of the failings of the sectors' relationships with its buyers. For example, one strategy of the sector is to protect against uncertainty by using an inventory of samples and design ideas and to facilitate postponement of product decisions through the integration of fabric, dyeing and printing, and garment assembly functions within the local supplier network. Nevertheless, there is an almost complete absence of information sharing upstream within the supply network, in 
particular from retailers to suppliers, exacerbated by the difficulty of predicting demand for new styles (Oxborrow\& Brindley, 2014).

Johnsen and Ford (2008) have found that power asymmetries affect the direction of relationships, while buyers and suppliers change their position of power during long-term relationships. The weaker party might experience difficulties in achieving its own business goals and consequently follows the stronger parties' decisions. Furthermore, power asymmetry jeopardises the relationship development efforts of the weaker party, although the latter do gain power and overcome asymmetries as the relationship develops (Lee \&Johnsen, 2012). Consequently, it is important to consider power types, which are mainly exerted by the buyers and portray these asymmetries.

In the literature, power has been categorised into two areas; coercive and non-coercive power. Non-coercive power is defined as building upon rewards, being legitimate, and reverent, expert and informational. Coercive power uses penalty rather than reward to control another party (Benton \&Maloni, 2005; Terpent \& Ashenbaum, 2012). However, Gaski (1984) has criticised this classification because it ignores the other effects of power in supply chain relationships. Moreover, power asymmetries have been likened to coerciveness because coercive power takes place if there is a low level of commitment and conflicting relationships and where one party is strongly dependent on the other (Ford et al., 2003). It diminishes the chance of cooperation between parties and long-term successes. In contrast, non-coercive power affects the relationship positively by increasing motivation and cooperation, and offering more negotiation opportunities for the weaker party (Lacoste \&Johnsen, 2014). However, our knowledge of power is still limited in supply chain relationships (Meehan \& Wright, 2012). In addition to this, there is also very limited understanding of the performance of power and there is a real dearth of research into the nature and character of buyer-seller 
relationships in the specific context of the apparel industry and the role of capabilities. This paper will address this point.

\subsection{Supplier Capabilities to Overcome Power Asymmetry}

The capability of a firm is its ability to achieve against the hostility of circumstance or strong competition (Mintzberg \& Quinn, 1992). In dyadic relationships, interaction utilises the capabilities of a company but may also determine capability development over time (Ford, Hakansson, \& Johanson, 1986). In asymmetrical relationships, suppliers' capabilities may be employed by the customer to gain benefit, but alterations may only be permitted when needed by customers (Johnsen\& Ford, 2002).

Harrison (2004) depicted that asymmetry is an unchallengeable condition that small suppliers have to accept to survive in relationships with large buyers and to gain benefit from their experience and network contacts. However, some researchers have found that small firms

often have strengths and capabilities that are critically important to their more powerful partners (Johnsen \& Ford, 2006). Similarly, small firms may influence the nature of relationships with buyers, by focusing on the priorities of customers, offering competitive advantage and developing expertise in these particular areas (Caniels \& Gelderman, 2007).If such a capability exists, the relationship moves towards a more symmetrical state. Contrastingly, small suppliers can spend most of their energy and time in developing a relationship with their most important buyer that then 'locks' them into this relationship, hindering their ability to achieve their own goals, such as developing different customers or networks (Lee \& Johnsen, 2012; Munskgaard, Johnsen \& Patterson, 2015).

Furthermore, a growing body of literature has indicated that asymmetric relationships may provide both opportunities and difficulties in relation to the capabilities of smaller suppliers, such as developing capabilities in management, leadership, technology, collaboration and interaction (Chen \&Chen, 2002; Holmlund, 2004). As Wowak et al. (2015, p: 9) posited, the 
buyer can have a significant dependence on the supplier due to the supplier's "unique capabilities", thus creating power asymmetry but providing some security for the SME. However, this may lead the buyer to decideon acquisition or a strategic alliance (Wowak et al., 2015). The difficulties are mainly related to the limited ability of smaller suppliers to develop and maintain a set of capabilities for growth, building a competitive position and creating value (Johnsen and Ford, 2006). However, opportunities are afforded by asymmetry since smaller suppliers in the relationship absorb and influence external knowledge and practices through their collaboration with large buyers (Blomqvist, 2005).Indeed, as Johnsen \& Ford (2002, p: 12) expressed, 'a company's relationship affects its capabilities and its capabilities affect its relationship'.

Capabilities are considered the most important distinguishing factor for a company and they strongly support companies to gain a strategic advantage over others (Leonard-Barton, 1992; Prahalad and Hamel, 1990).A number of recent studies in supply chain relationships, new product development, and value creation addressed the importance of capabilities in a company's success; (Johnsen, 2009; Sirmon et al, 2011 and Wowal et al, 2015). In this research, we will build on Leonard-Barton's (1992) capability framework by exploring small apparel suppliers' capabilities in asymmetric relationships. Leonard-Barton's capability framework enables us to capture and identify organisations' internal capability sets, as well as the tangible and intangible resources that help them to achieve competitive advantage by becoming a preferred supplier. However, the application of Leonard-Barton's framework and identification of the internal capability sets of organisations would be insufficient alone without understanding when and where to apply them appropriately in order to overcome asymmetry. Leonard-Barton's capability framework consists of knowledge based, technology based, managerial system based and value and custom based core capabilities. 
By discussing the key firm specific capabilities that help supplier firms to overcome power asymmetries in their relations with buyers we address the second research objective 'how SME suppliers mitigate against any identified power asymmetry'.

\subsection{Four Types of Capability}

2.3.1. Employee Knowledge Based Capability is embodied in employee knowledge and skills (Leonard-Barton, 1992, p:3). 'Over time, firms' knowledge, accumulated through 'learning by doing,' is embedded in bundles of 'routines' that are likened to the genetic material of the firm'. Tacit, personalised knowledge cannot be easily conveyed to the partners (Teece, 1998), whereas explicit knowledge is less difficult to convey and is exchanged through interpersonal interactions (Nonaka and Takeuchi, 1995).Moreira (2009) stated that developing relationships with partners increases organisational learning and knowledge development. This in turn increases capability development, decreases the time and risk involved in new product development and technologies (Nguyi, Johnsen \& Erdelyi, 2010), while generating synergy for further knowledge creation enabled by both parties' involvement (Ethiraj et al., 2005).'The firm's knowledge base reflects individual skills and experiences as well as distinctive ways of doing things inside firms' (Teece, 1998, p 23). The embedded capability within the company thus includes technological competences and knowledge of customer needs and supplier capabilities and therefore facilitates responsiveness to customers' product specific requirements (Olson et al., In their relationships with retailers, suppliers can implement and develop their knowledge base capabilities through interpersonal interactions, such as in product development, but the sustainability of the relationships depends on justice and fair play (Wowak et al., 2015). 
2.3.2. Technology Based Capability is knowledge embedded in technical systems, developed from the long-term codifying and structuring of employees' tacit knowledge. This knowledge constitutes both information and procedures (Leonard-Barton, 1992) through co-ordination of various production skills and their integration into multiple technologies (Prahalad \& Hamel, 1990).Business relationships provide development opportunities for the technical capacity of the firms (Hakansson \& Snehota, 1995). Joint involvement of suppliers and buyers helps to identify which technical capabilities to focus on and develop, and facilitates early identification of problems and opportunities for technological knowledge exchange and capability development between the parties. Joint development of technical capabilities enables suppliers to be more flexible in their operations and apply their capabilities across different buyer relationships (Johnsen and Ford, 2006). Suppliers with technical capability are highly sought after and preferred by buyers(Hakansson and Snehota, 1995) so it is vital to develop the technological capability of suppliers by enlarging the suppliers' technical systems and technological innovations, and providing opportunities for combining those available technologies into the wider network (Nguyi, Johnsen \& Erdelyi, 2010).

Corsaro \& Snehota (2011) argued that joint interests and goal alignment provide a high degree of effectiveness and attachment in relationship specific activities, especially important as the complexity of relationships and production processes increase. However, pursuing selfinterest in asymmetric buyer relationships enables suppliers to experience better outcomes, because self-interest dominates the relationship and focuses that party's resources for developing technology (Munkusgaard, Johnsen \& Patterson, 2015).

2.3.3. Managerial System Capability is a process that controls knowledge in relationships, influencing corporate structures and bonds(Leonard-Barton, 1992).Consequently, managerial systems capability may shape relationship characteristics by developing management structures and resources able to support a supplier to integrate into a better management 
system and access the resources of its partner (Nguyi, Johnsen and Erdelyi, 2010). Furthermore, managerial system capability involves communication and commitment across organisational boundaries, involving people from every level and all functions (Prahalad \& Hamel, 1990).

It is important for a company to sense and grab the opportunity. Organisations able to access external resources and combine them with internal resources can do this (Teece, 1998).For example, managerial system capability supports new product development because supplierbuyer relationships depend on internal coordination, supplier selection processes, and longterm relationship adaptation to create supplier relationships with high levels of trust and commitment (Johnsen, 2009). Consequently, inter-firm relationship management has been considered as creating value streams that it would not be possible to create independently (Esper \& Crook, 2014). Moreover, managerial system capability is important to suppliers in relationships with large customers, as it enables suppliers to acquire the capability to understand the planning and relationship implications of working with large customers (Ford et al., 2003).

2.3.4. Values and Norms Based Capability: values enable knowledge creation, embedded in management practices that influence planning and projects in the line of doing business (Leonard-Barton, 1992). Delivery of value is a competence in itself (Prahalad \& Hamel, 1990). Foss (1999) stated that there is a clear link between capabilities and values and norms, thus it is also important to understand the function of capabilities in relationships. For example, a culturally dominant buyer might influence supplier company culture, or a supplier that manages intercultural relationships could gain a better position (Johnsen \& Ford, 2006).

Norms guide and rule related exchange processes (Hakansson \& Snehota, 1995).For a firm to gain legitimate status in relationships, it must understand formal institutional rules and regulations as well as informal institutional norms and values of its partners (Webb et al., 
2009). In addition, communicating values to new large customers is important for suppliers in order to put forth their values and position themselves in relationships. Accepting and relying on the new large customers' values and norms will make the suppliers reduce their own cultural identity (Johnsen \& Ford, 2006). Furthermore, learning and understanding customers' culture and values would help suppliers to be able to handle conflict and discrepancy in relationships, thus it is important to create a shared culture and values that enable both parties to develop strength and further value creation for their relationship(Nguyi, Johnsen \& Erdelyi, 2010).

Having acknowledged the four types of capability and the consequences of power asymmetry for suppliers in the literature, a framework has been created from which to conduct further research and analyse the data. Leonard-Barton's (1992) four-type capabilities classification work was firm-specific, but the focus of this research has been on relationships of suppliers with retailers, therefore, we have adapted this capability classification into relationship specific capabilities. The resource-basedview and strategic management have discussed different types of capabilities and their relevance to the firms (Foss, 1999; Teece, 1998; Sirmon et al., 2011; Wowak et al., 2015) but do not fully explain relational aspects of capabilities in the inter-relationships of companies. They have, however, offered a basis and complementary view to explain capabilities and directed our attention to the limitation of the literature. From this basis and complementary views, we identified four types of capability including employee, technical, managerial and custom capabilities.

This provides the opportunity to test whether the framework still represents the accumulation of capabilities, specifically within small supplier firms, and the nature of any connections between the accrual of different capabilities and small firms' experience of asymmetrical power relations. 


\section{Conceptual development to examine small apparel manufacturers' capabilities in asymmetric relationships with retailers}

From our understanding of a range of core relational capabilities in SMEs, based on tangible and intangible aspects, we aim to distinguish how small apparel suppliers provide competitive advantage that may influence how, when and where they can overcome power asymmetry in their relationships with buyers. The Concept of asymmetry and symmetry, and capability set of suppliers -namely knowledge, technology, managerial and custom- were combined to develop the framework outlined in Table 1.The framework indicates how each individual relationship characteristic is manifest in a supplier and retailer relationships and guides the development of the empirical study.

Table 1: A FRAMEWORK OF SUPPLIERS' CAPABILITIES IN ASYMMETRIC ANDSYMMETRIC RELATIONSHIPS

\begin{tabular}{|c|c|c|c|}
\hline $\begin{array}{l}\text { Types of } \\
\text { Capabilities }\end{array}$ & Asymmetry & Symmetry & Indicators \\
\hline $\begin{array}{l}\text { Employees } \\
\text { Capabilities }\end{array}$ & $\begin{array}{l}\text { Supplier's employees } \\
\text { involve necessary activities } \\
\text { with buyer's employees. } \\
\text { Supplier's employees need } \\
\text { to perform better and accept } \\
\text { the control of buyer. }\end{array}$ & $\begin{array}{l}\text { Satisfactory joint employee } \\
\text { activities in various areas } \\
\text { from supplier and buyer. } \\
\text { Combined knowledge } \\
\text { generation by sharing } \\
\text { experiences and different } \\
\text { knowledge sets. }\end{array}$ & $\begin{array}{l}\text { Supplier involved in collaborative } \\
\text { projects and tasks. } \\
\text { Supplier will have better } \\
\text { opportunities to gain market, } \\
\text { technical and financial benefits. }\end{array}$ \\
\hline $\begin{array}{l}\text { Technical } \\
\text { Capabilities }\end{array}$ & $\begin{array}{l}\text { Necessary development of } \\
\text { technical capabilities } \\
\text { directed by buyer. } \\
\text { Supplier develops dependent } \\
\text { and buyer oriented } \\
\text { technologies. }\end{array}$ & $\begin{array}{l}\text { Satisfactory joint } \\
\text { development of technology. } \\
\text { Better technological } \\
\text { knowledge sharing. }\end{array}$ & $\begin{array}{l}\text { Suppliers technology needs will be } \\
\text { identified in advance and solutions } \\
\text { will be found collaboratively. } \\
\text { Supplier becomes accustomed to } \\
\text { different technologies and their use } \\
\text { in different relations. }\end{array}$ \\
\hline $\begin{array}{l}\text { Managerial } \\
\text { Capabilities }\end{array}$ & $\begin{array}{l}\text { Necessary development of } \\
\text { plans and business } \\
\text { objectives in the direction of } \\
\text { buyer. }\end{array}$ & $\begin{array}{l}\text { Satisfactory joint } \\
\text { development of plans and } \\
\text { business objectives which } \\
\text { are beneficial for both }\end{array}$ & $\begin{array}{l}\text { Supplier predicts and offers } \\
\text { solutions to solve difficulties in } \\
\text { relations. }\end{array}$ \\
\hline
\end{tabular}




\begin{tabular}{|l|l|l|l|}
\hline \multirow{5}{*}{$\begin{array}{l}\text { Supplier needs buyer's } \\
\text { advice in various areas to } \\
\text { manage its resources and } \\
\text { manufacturing activities. }\end{array}$} & $\begin{array}{l}\text { parties. } \\
\text { ability to develop different } \\
\text { management capabilities for } \\
\text { different partners. }\end{array}$ & $\begin{array}{l}\text { Supplier is able to manage diverse } \\
\text { customers. }\end{array}$ \\
\hline Custom & $\begin{array}{l}\text { Supplier becomes more } \\
\text { familiar with the buyer's } \\
\text { norms and values than the } \\
\text { buyer does for those of the } \\
\text { supplier. }\end{array}$ & $\begin{array}{l}\text { Both parties learn each } \\
\text { other's norms and values in } \\
\text { order to understand the } \\
\text { process of knowledge } \\
\text { sharing. }\end{array}$ & $\begin{array}{l}\text { Supplier becomes experienced in } \\
\text { understanding of buyers' principles } \\
\text { and techniques to use and gain from } \\
\text { this knowledge. } \\
\text { Supplier is able to use this }\end{array}$ \\
& $\begin{array}{l}\text { Supplier learns buyer's } \\
\text { country or business culture. }\end{array}$ & $\begin{array}{l}\text { Both parties also learn each } \\
\text { other's country or business } \\
\text { culture. }\end{array}$ & $\begin{array}{l}\text { capability for different customer } \\
\text { relationships. }\end{array}$ \\
\hline
\end{tabular}

Source: Table 1 adapted from Leonard-Barton (1992)'s fourfold capability framework.

\section{Methodology}

\subsection{Case Study Approach}

The research design adopts a multiple exploratory case study approach (Yin, 2003) to enable rich data to be gathered on the experiences of asymmetry in the apparel supply chain. Reaching general conclusions in the light of the data derived from case studies are achievable in a multiple-case approach when only limited knowledge is available about the phenomenon (Halinen \& Tornroos, 2005). For this research, UK and Turkish apparel suppliers have been selected to explore how capabilities help suppliers to overcome asymmetries in relationships with retailers. It is recognised that a comparative approach helps understanding of similarities and differences in each case (Coviello \& Jones, 2004; Eisenhardt, 1989). Furthermore, theoretical saturation is achieved in the light of Yin's (2003) approach of choosing case companies that fill those themes prioritised to extend emerging theory. Consequently, we filled the theoretical categories of four types of capabilities to extend the emerging theory on power asymmetry in dyadic relationships. 
Apparel suppliers were selected from the UK and Turkey as the result of the established presence of the apparel industry in both countries. This established presence offered a platform to explore power asymmetry in supply chain relationships in the same industry but in two different countries. In addition, the apparent long term supply relationship characteristics of both UK and Turkey's apparel suppliers' with their retail customers, primarily in the UK and Europe, led the researchers to focus on these two countries' apparel suppliers for exploration. Lastly, the sharp contrast of sourcing strategies of both-- the UK's suppliers have off-shore production and out-sourcing experience, while Turkish suppliers lack this experience -- led researchers to explore this contrast.

The authors have developed a longitudinal relationship with the sample cases in order to identify developments or alterations in the capabilities of case companies at an individual level and as comparison to other case companies. Data was captured through semi-structured interviews based on key themes from the framework, focusing on dimensions of capabilities, the nature of relationships and strategies to overcome asymmetry. The capability framework enables us to capture and identify the organisations' internal capability sets as well as tangible and intangible resources. Therefore, open-ended questions were used to explore each apparel suppliers' experiences and approaches in their relationships with retailers.

\subsection{Selection of Case Companies}

The Turkish sample was derived from a list obtained from the Istanbul Trade Association; this list was reduced from 5,000 to 250 companies using 4 criteria: they are regular exporters, registered with the association, SMEs, and apparel manufacturers. All 250 were emailed asking if they would take part in an interview and 25 positive responses were received. After a follow up telephone call, attrition attributed to time constraints and unwillingness to divulge sensitive data left 10 companies with whom interviews were arranged. For the UK sample, comparable information was sought from the Association of Suppliers to the British Clothing 
Industry database, which yielded around 40 manufacturing contacts, boosted to 95 through a regional trade association and consulting the FAME database. Those that were SME and apparel manufacturers with UK facilities were contacted by email and telephone, from which 16 agreed to be interviewed and 10 interviews were conducted. Attrition was attributed as above. Interviews in Turkey and the UK were structured around the prioritised themes but we were flexible when listening to respondents' comments in order to reach saturation and expand important points and events. Each company was interviewed twice over one year period.

\subsection{Data Analysis}

Interviews were tape recorded and transcribed and the data collected in Turkey was translated into English. Each interview lasted one to one and half hours. The transcripts were annotated to generate first level coding (Miles \& Huberman, 1994). A coding sheet was generated, based on emerging themes arising from the interviews and the framework helped with grouping these emerging codes into themes for the further steps in reducing, displaying and interpreting the analysed data. The analytical approach was chosen in this research to relate the interview data to research objectives using those themes derived from the framework of supplier capabilities and asymmetric relationships. The analysis resulted in a number of common issues, including those raised by the SMEs themselves in discussion, as well as those apparent in, or in contrast to the literature. These common patterns are summarised in Table 2below.Cases A to $\mathrm{J}$ are located in Turkey, whilst cases $\mathrm{K}$ to $\mathrm{T}$ are based in the UK.

The Meta-matrices (Table 2) were used for the cross-case analysis (Miles \& Huberman, 1994). Meta-matrices, in this study, provided both analytical generalisations from the individual case study findings, while generating a holistic picture of intra and inter-firm interpretations, thus providing both external and internal validity(Yin, 2003).This approach 
supported our intra case comparisons and highlighted similarities and distinctions between the cases, enabling us to draw conclusions from the findings of this empirical study. Insert Table 2 here. 


\section{Findings}

\section{In this section, the research findings addressed the first objective of the research: 'To identify}

the power asymmetry in the buyer/supplier interface in the apparel industry' by identifying asymmetries in relationships.

The findings support the enhancement of the typology of suppliers' capabilities in asymmetric and symmetric relationships in a revised version of the framework outlined in Table 1.The findings in this study (See Table 2) reveal power asymmetry in the apparel industry in Turkey and the UK and illustrate how capabilities have enabled suppliers to overcome power asymmetry in relationships.

All suppliers are supplying large organisations, primarily retailers, who demonstrate aspects of both coercive and non-coercive power to influence the direction of their SME suppliers, consistent with Johnsen \& Ford (2008) and resulting in the 'lock-in', observed in the literature (Lee \&Johnsen, 2012; Munskgaard, Johnsen, \& Patterson, 2015).Consequently, the majority of the suppliers are dependent on relatively few retail customers and they provide contract manufacturing services, predominantly production for those based in Turkey and combined production and sourcing for those in the UK.

The impacts of power asymmetry are felt in a number of ways: while control of price is important, as found by Johnsen and Ford (2006), financial control is further exerted through deleterious payment terms and the imposition of penalties and retrospective discounts or charges to contribute to promotional and markdown costs. However, asymmetry is also found to contribute to responsiveness in a detrimental way, with evidence of contractual lack of clarity, changes to terms and conditions, inventory risk placed with the supplier, and last minute changes or even cancellation of orders - all for the benefit of the power-bearing customer. 
The second objective of the research: 'To understand how SME suppliers' capabilities mitigate against any identified power asymmetry' was answered by exploring the responses of both UK and Turkish suppliers in more detail. This also contributed towards an exploration of the third objective, drawing on the contrasts and similarities between the UK and Turkish suppliers in the following section.

In spite of the size differences and apparent relationship asymmetry, the SME suppliers in our sample are not passive in their relationships, and are found to have influenced the dynamics of their relationships over time. The strategies employed are closely aligned to the range of capabilities that they exhibit (Johnsen\& Ford, 2002). As a minimum, suppliers use their production and technical capabilities to create inter-dependencies by enhancing product performance, engineering products to price thresholds and sourcing materials or components. One UK supplier explains how this compensates for the buyers' lack of technical and production knowledge and experience. Since one would expect suppliers to have a degree of production expertise, this is unsurprising.

A further strategy to create dependency is to exploit the benefits of flexible supply. Half of the UK suppliers and the majority of the Turkish ones are able to provide flexible and responsive manufacture, with short lead-times from order to delivery combined with the capability to react to changes in the market and to communicate with customers relating to order fluctuations. These strategies are supported by management capabilities that support the development of personal relationships, often involving the owner and/or key account management. While these capabilities may be deployed to appease buyers, and create interdependency, the evidence does not support any dynamic move towards symmetry. Indeed, suppliers talk of being expected to absorb price pressures and assume considerable risk, particularly in the interests of pursuing flexibility. Retailers continue to set the rules of the game (Hingley, Angel, \&Lindgreen, 2015). 
In this context, UK suppliers are able to react differently to their Turkish counterparts, as a result of the legacy of relationships in the UK apparel supply chain, their proximity and a number of externalities particular to the enduring core of the UK apparel industry. While the Turkish manufacturers concentrate on production and technical capabilities, the UK suppliers are often expected to take on additional risk by subscribing to a call-off system, supplying and selling pre-ordered goods only in response to actual sales, or holding materials speculatively to respond to very short lead times of two to four weeks. Furthermore, because most have down-sized, but retained access to owned or outsourced UK manufacturing capacity, they are able to offer sourcing options from the UK before off-shore, depending on speed or cost priorities. While reinforcing inter-dependency or countervailing power(Lacoste \&Johnsen, 2014), these strategies are not without cost to the supplier, with one explaining how their owned, onshore production capability has become under-utilised, in favour of new found sourcing skills.

The final advantage displayed by the UK suppliers is the buy-in of specific personnel to strengthen the development of personal relationships. Drawn primarily from the largely redundant legacy of large UK suppliers, six of the UK respondents have hired designers or former buyers with good knowledge of the market, extensive personal contacts and cultural ties closer to those of the buyers (primarily female and ethnically white British). This move towards the customers' values and norms (Johnsen and Ford, 2006) has enabled the suppliers to offer a full design and sampling service, proactively design for the market place and even attempt to opportunistically 'manage' the buyers by expediting design and ordering decisions, and generating a degree of capability-based buyer dependence on the supplier (Wowak et al., 2015).

Given these inter-dependencies, the relatively small UK suppliers have learnt to manipulate asymmetrical relationships by saying 'no' until an operational win-win scenario is negotiated 
with regard to aspects such as unrealistic lead-times, price negotiations and last minute style changes. Of further note, those suppliers with integrated upstream supply, often family owned, have more symmetrical relationships upstream, whereas those sourcing from independent suppliers are increasingly finding that highly sought-after, good suppliers in the Far East are also able to exert asymmetrical power on smaller retailers and sourcing companies.

In contrast, our findings indicate that the majority of Turkish suppliers have limited authority over their supply strategy, due to their dependence on buyers for information relating to product requirements, price, market knowledge and technical procedures. Moreover, suppliers may accept short-term losses in order to obtain long-term benefits. Thus, suppliers become more tolerant to the requirements of their customers and flexible in production processes. Turkish suppliers also employ personal relationships with their most preferred buyer and less formal relationships that help to make quick progress through relationship building efforts (Johnsen\& Ford, 2008). On the other hand, personal relationships generate uncertainties and difficulties for suppliers aiming to establish a long-term business focus. Suppliers try to provide more tailored responses in their day to day interactions with customers by putting excessive pressure on themselves and their business to exceed the buyers' needs. Lastly, personal relationships also impact on their negotiation power, since they feel the necessity to sacrifice more in order to gain more. Personal relationships and ties are also important in local relations between suppliers and industry players in the upstream apparel supply chain.

Technological advancements in production are another strong hold for Turkish suppliers that allow them to be flexible and fast in both time and quantity of production. Moreover, offering tailor-made production, updated designs and alternative, cost-effective production techniques to their buyers demonstrate show Turkish suppliers position themselves in relationships. In 
addition, Turkish suppliers see that it is necessary to offer technical solutions, along with new offers for their customers, before the production process starts in order to strengthen their ties (Lacoste \&Johnsen, 2014). This is a vital capability which also manoeuvres them into a position where they can be nominated as the most preferred supplier.

It is evident that personal relationships are employed by suppliers and have become an important managerial capability in relationships with buyers as they help suppliers to be flexible in production when there is no scheduled production plan. Lastly, all Turkish suppliers are aware of research and development as a significant way to remain a listed supplier, so this technical area has become associated with their employee capabilities. Unlike UK's suppliers, Turkish suppliers employ in-house designers rather than freelance designers, providing consistent support for their customers' needs and enabling employees to benefit from long-term development of their knowledge and experience.

Finally, Turkish suppliers gain benefit from a distinct market-customer portfolio when they try to overcome power asymmetry in their relationships. By developing relationships with buyers from a number of markets the Turkish SMEs are able to learn from this diverse portfolio and use this shared knowledge to develop innovative production techniques and provide solutions to a cross-section of buyers. These solutions, based on knowledge drawn from a number of different market experiences, provide a base to strengthen their relationships with buyers as they gain power and mitigate power asymmetries as the relationship develops (Lee \&Johnsen, 2012). It is also a means of enhancing organisational learning in the buyers as posited by Ehrgott et al (2013) as they learn about the capabilities of the suppliers. This shows mutual custom-based capabilities as Turkish suppliers adapt their buyer's culture and also learn more from them. Turkish Suppliers adhere to their customers' culture and non-coercive power, but this provides suppliers considerable opportunity to offer tailor-made responses and understand customer expectations. Adapting quality standards in 
production, design and relationships from a diverse range of markets and customers enables Turkish suppliers to contribute design and technical solutions to maintain their creativity and foster inter-dependency in their relationships.

\section{Discussion}

It is evident that in the relationships between suppliers and retailers, power asymmetry is evident and remains challenging for apparel suppliers in both countries as a result of power exertion by retailers (Oxborrow\& Brindley, 2014).The findings are in line with the earlier study of Meehan \& Wright (2012) concerning the dramatic shift in the balance of power, from suppliers to retailers. The findings clearly show that power asymmetry is evident in both countries' supplier-buyer relationships in the apparel industry. This research has identified the power asymmetry in the area of technical and managerial interactions that force apparel suppliers to develop their technical capabilities in the directions that retailers prefer. Meanwhile, apparel suppliers follow the retailers' business objectives in managerial issues, such as price controls and contractual decisions. Moreover, power asymmetry is also evident in employee and customer interactions in those apparel suppliers' employees are consistently more committed to the relationships than those of the retailers in order to deal with frequent changes and apparel suppliers adopt retailers' norms and values to support long term business relationships. These findings are consistent with Hingley et al.'s (2015)'s view that retailers continue to hold power and remain dominant.

The discussion follows the themes drawn from the framework (Table 1), which guided this research to examine suppliers in both countries, in order to explore their mechanisms for overcoming asymmetry in supply chain relationships and achieving symmetry by developing capabilities in four areas (Hakansson \& Snehota, 1995). In particular, this research facilitates an inductive approach, linking industrial marketing management literature, to which we turn for a more detailed conceptual explanation of how symmetry can be achieved, and the 
framework, which broadly indicates what can be achieved most in asymmetric relationships. This is reflected in Table 1, which shows the inductive process from primary data collected from the case, cross-referenced to asymmetric power concepts, and linking these to marketing approaches, whilst highlighting the importance of considering capabilities within the relational paradigm (Johnsen \& Ford,2006;Ford, Gadde, Hakansson, \& Snehota, 2003).

The following section answers the third objective of the research in detail: 'To evaluate whether there are any differences or similarities between the approaches of apparel SMEs based in the UK and Turkey'.

\subsection{Employee Capabilities}

Unlike UK's suppliers, Turkish suppliers prefer to keep their employees on long-term contracts, employing in-house designers to gain the maximum benefit from developing employee capabilities within the firm. In addition, Turkish employees are also encouraged to take and utilise regular training for developing their skills and competencies, mainly at the request of retailers. This has also offered Turkish employees a chance to become involved in collaborative bilateral activities with buyers' company employees. Therefore, Turkish suppliers were able to mitigate employee knowledge related power asymmetry, in line with Ethiraj et al. (2005, p:28), who suggest that: 'Over time, firms' knowledge, accumulated through 'learning by doing,' is embedded in bundles of 'routines' that are likened to the genetic material of the firm'. On the other hand, interpersonal relationships are considered as important to develop employee capabilities by knowledge sharing within relationships (Wowaket al., 2015) and Turkish suppliers enjoy personal relationships with their retail buyers. However; UK suppliers were more likely to engage outsourced supply to meet the demand of buyers and often hired freelance designers, though sometimes on long term contracts, chosen because of their prior learning and existing interpersonal relationships. In this case, learning by doing depends on different contexts brought into the firm by the 
freelancer to the UK apparel suppliers, based on prior experience gained elsewhere, an interesting take on Teece, (1998) who advocates distinctive ways of developing capability. UK suppliers thus face the challenge of developing both internal employee capabilities and network capabilities across their outsourced manufacturers and freelance designers, the latter supported by steady downsizing within the UK apparel industry (Lowson, 2003). This influences the way UK suppliers mitigate power asymmetries.

\subsection{Technical Capabilities}

Turkish suppliers have strong technical capabilities, which give them an advantage in their relationships with buyers. The technical capabilities of Turkish suppliers provide competitive advantages such as flexible, fast and cost effective production offers for their buyers, resonating with the findings of Leonard-Barton (1992) who found that embedded technical knowledge, results from years of accumulating, codifying and structuring tacit knowledge. While the technical capabilities of suppliers developed through relationships with buyers (Hakansson \& Snehota, 1995) as a way to overcome asymmetry in relationships this also gave rise to a limitation for suppliers, because they became locked-in to these relationships. Turkish apparel suppliers, with their experience of working for buyers in different markets, developed a broader set of technical capabilities, which proved to be less relationship specific. Indeed, this helped them to offer fast and flexible production capability technical solutions and new offers early in the production process, strengthening their ties and enabling them to mitigate power asymmetry in their relationships (Lacoste \&Johnsen, 2014). On the other hand, for UK suppliers, their outsourcing, overseas production experience and vertical integration upstream provides a material advantage, while being positioned as 'trial' suppliers enables them to mitigate power asymmetry by being seen as problem solvers. This concurs with Prahalad \& Hamel's (1990) findings that combining experiences of working with different partners helps to coordinate a range of production skills. Furthermore, in the UK, 
apparel suppliers have advantages when they deal with power asymmetry, having a long tradition of apparel industry culture and practices, which enable them to gain capabilities from lengthy exposure to formal and informal buyer practices, consistent with Webb et al. (2009).

\subsection{Managerial Capabilities}

Personal relationships have largely been employed in relationship management by Turkish suppliers, which have created a relatively informal approach to relationships, although this proved to be a limiting factor in price negotiations and created a lack of contractual clarity with buyers. Indeed, Turkish suppliers mitigate power asymmetry in managerial areas by investing resources in frequent production changes; collective projects with buyers and providing production flexibility to create inter dependency. Consequently, inter-firm relationship management can create value streams that would not be possible to create independently (Esper \& Crook, 2014; Ford et al., 2013).

Leonard-Barton (1992) suggested that controlling knowledge can be achieved in either formal or informal ways. Turkish suppliers rely predominantly on informal ways, while some UK suppliers, with their advanced negotiating and problem solving abilities, were able to say 'no' until a win-win situation was found. However, they also were expected to take additional risks by anticipating demand and holding stocks speculatively to respond to very short lead times. These were important managerial based capabilities that help to develop inter dependencies and mitigate power asymmetry in relationships with buyers. Teece (1998, p: 74) has emphasised that 'Once an opportunity is sensed, it must then be seized'. This is where the organisation's ability to quickly contract up the requisite external resources and direct the

relevant resources comes into play'. Hence, UK suppliers are also strong in off-shore sourcing and outsourcing, that demonstrates their managerial abilities to commission a range 
of external resources when required, generating a degree of capability-based buyer dependence on the supplier (Wowak et al., 2015).

\subsection{Custom Capabilities}

Turkish suppliers were able to adapt buyers' norms, values and benchmarks in production and order processing that led them to offer custom made solutions and exclusive services for their buyers outside of their normal working practices. Cultural understanding and adaptation to buyer norms were considered valuable to the suppliers' efforts to develop interdependency, avoid conflict and inconsistency in relationships and mitigate against power asymmetry. This supports Nguyi, Johnsen \& Erdelyi's (2010) findings that handling conflict and discrepancy in relationships starts with learning and accepting others values, thus creating a shared culture and values that enable both parties to develop strength and generate value for their relationship.

In contrast, UK suppliers seemed to adopt buyers' norms and expectations. For example, some improved compliance with ethical working conditions, while Asian owned suppliers employed professional white male sales representatives and female designers, to look more adapting and engaging to their retailers' norms and values. This is consistent with the views advocated by Hakansson \& Snehota (1995) who suggested that the norms serve as rules and guidelines for the ongoing exchange processes, and the assertion of Johnsen and Ford (2006) that adopting the customers' norms means suppliers compromising on their own cultural identity.

\subsection{Power Asymmetry and Symmetry}

It is evident that capabilities in four key areas namely, employee, technical, managerial and custom help suppliers to develop inter dependencies in asymmetric relationships. In fact, this can support the idea of collective interest created through inter-dependences by using combined capabilities in fast fashion supply. Building on Johnsen and Munsgaart's (2015) 
collective interest illustrates how suppliers' competences develop and attract retailers; how inter-dependences are built and additional value delivered through these, and moreover how a degree of capability-based buyer dependence is generated by the supplier (Wowak et al., 2015). This is consistent with the countervailing power concept of Lacoste \& Johnsen (2014). Thus, this illustrates the positioning of suppliers in asymmetric apparel supply chains, even at a time when retailers have increasing power over their suppliers (Hines \& McGovan, 2005).

\section{Conclusions}

\subsection{Contribution of study}

The conceptual developments of the paper aimed to contribute to emerging theoretical discussions on the nature of asymmetric relationships and capabilities from an IMP perspective. The research has contributed to the field that explores the character of asymmetry in dyadic relationships (Hingley, 2005; Johnsen \& Ford, 2008).

Building on an interaction approach, we set out to explore how apparel suppliers overcome power asymmetry by using their capabilities in relationships with retailers. This study has built on previous research that has examined asymmetry in supplier buyer relationships (Johnsen \& Ford, 2008; Lee \&Johnsen, 2012) and the capability sets of organisations (Johnsen and Ford, 2002 and Leonard-Barton, 1992). In contrast to earlier work the research extends to industry level, rather than that of the individual firm (Leonard-Barton, 1992). Furthermore, our research is amongst the first to examine power asymmetry and capabilities of small apparel suppliers in the context of asymmetric relationships in two countries Turkey and The United Kingdom with data collected from both, which demonstrated some fruitful contrasts.

This is a significant contribution of the study, which has provided a framework by combining four sets of capabilities and their influence on asymmetry and symmetry in relationships. The 
framework has provided a direction for analysing data by focusing on suppliers' capabilities, while explaining how they overcome power asymmetries in relationships.

The first objective of this research in the apparel industry has been achieved by identifying asymmetry of association within supply chain relationships. Asymmetry is associated with responsiveness and cost control, encouraging suppliers to be fast and flexible, in return for non-coercive incentives, such as repeat orders and the opportunity to replenish other suppliers' styles. The impact of the longevity of relationships on power is also identified and is seen as more important than country of origin. It is this type of strategic supply chain management that in the apparel industry offers 'best value' and allows the supply chain 'to excel in terms of speed, quality, cost, and flexibility’ (Ketchen et al, 2007, p: 579).

The second objective of this research in the apparel industry provided a clearer understanding of how capabilities help to overcome asymmetries. Production and technical capabilities affect power asymmetry, but cause and effect is difficult to establish as these capabilities are fundamental to the relationship. Management capability is significant in a number of ways, as illustrated by the importance of managing relationships and mitigating the risks associated with these. Custom capabilities supported suppliers efficiently in their efforts to deliver value. The third objective of this research has identified contrasts and similarities between the approaches of UK and Turkish suppliers. For both Turkish and UK SMEs, it is the utilisation of their differing capabilities that enables them to be responsive. UK suppliers developed specific strategies around design and marketing knowledge as well as inventory management made possible by proximity. These suppliers demonstrate the dynamism of their relationships over time in that the level of inter-dependency or countervailing power appears to be relatively high, while the dynamism has accompanied a shift in supplier selling strategies towards fast fashion capability and problem solving (Lacoste \&Johnsen, 2014). Building on Nyaga et al., (2013), the findings suggest that asymmetric power from the buyer affects both 
the strategic and operational activity of the supplier, while the opportunism afforded to the supplier, and any countervailing power, is limited to operational areas of the weaker party. Furthermore, this opportunism is more prominent among the UK suppliers- although this could be explained by their longer relationship history and different role in the supply chain, rather than their country of origin. For the Turkish SMEs, it is their technological capabilities and diverse buyer markets, used in conjunction with personal relationships that are key.

\section{Future research directions}

It is acknowledged that overcoming power asymmetry may be a lifelong challenge for suppliers and as such a supplier must understand and evaluate its relationships with the buyer. This cross-cultural research in the UK and Turkey has provided a platform for further longitudinal study with the research participants. Future research will focus on the frequency

of power usage patterns by large buyers in relationships with small suppliers, providing evidence to support the dynamic nature of power in asymmetric relationships. In addition, the research design will explore power asymmetry, by examining both suppliers' and buyers' perspectives concurrently to offer rich observation and exploration.

A further research stream will focus on the less tangible socio-cultural relationship benefits particularly the issue of tacit and codified knowledge sharing. There are of-course further opportunities to extend the study to other industries and sectors. Moreover, different country contexts and their comparisons would provide richer insights and understanding in supply chain management. 


\section{References}

Belaya, V., Gagalyuk, T., \& Hanf, J. (2009). Measuring Asymmetrical Power Distribution in Supply Chain Networks: What is the Appropriate Method? Journal of Relationship Marketing, 8, 165-193.

Benton, W., \& Maloni, M. (2005).The influence of power driven buyer/seller relation- ships on supply chain satisfaction. Journal of Operation Management, 23(1),1-22.

Blomqvist, K. (2005). Trust in a Dynamic Environment - Fast Trust as a Threshold Condition for Asymmetric Technology Partnership Formation in the ICT Sector, Trust in Pressure, Investigations of Trust and Trust Building in Uncertain Circumstances in Edward Elgar Publishing, Inc. 127-147.

Caniels, M.C.J., \&Gelderman, C.J. (2007). Power and interdependence in buyer supplier relationships: A purchasing portfolio approach. Industrial Marketing Management, $36,219-229$.

Chen, H., \& Chen, T-J. (2002). Asymmetric strategic alliances: a network View. Journal of Business Research, 55(12), 1007-1013.

Chicksand, D. (2015). Partnerships: The role that power plays in shaping collaborative buyer-supplier exchanges. Industrial Marketing Management, 48(1), 121-139.

Corsaro, D. \& Snehota, I. (2011). Alignment and Misalignment in Business Relationships. Industrial Marketing Management, 40(6): 1042-1054.

Connelly, B.L., Ketchen, D.J. and Hult, M. (2013) Global supply chain management: toward a theoretically driven research agenda. Global Strategy Journal, 3, 227-243

Cox, A. (1999). Power Value and Supply Chain Management. Supply Chain Management: An International Journal, 4(4), 167-175.

Cox, A., Sanderson, J., \& Watson, G. (2001). Power regimes: A new perspective on managing 
in supply chains and networks. 10th international annual IPSERA conference, Jonköping, Sweden. 215-227.

Cox, A. (2004). The art of the possible: Relationship management in power regimes and supply chains. Supply Chain Management: An International Journal, 9(5), 346-356.

Coviello, N. E., \& Jones, M. V. (2004). Methodological issues in international entrepreneurship research. Journal of Business Venturing, 19(4), 485-508.

Craighead, C.W., Tomas, G., Hult, M., \& Ketchen, D.J. (2009). The effects of innovation cost strategy, knowledge and action in the supply chain on firm performance. Journal of Operations Management, 27, 405-421.

Dwyer, F.R., Shurr, P.H., \& Oh, S. (1987). Developing buyer-seller relationships. Journal of Marketing, 51(2), 11-27.

Eisenhardt, E. M. (1989). Building theories from case study research. Academy of Management Review, 14(4), 532-550.

Emerson, R. M. (1962). Power-Dependence Relations. American Sociological Review, 27(2), $31-41$.

Ehrgott M., Reimann F., Kaufmann L. Carter C.R. (2011). Social Sustainability in Selecting Emerging Economy Suppliers. Journal of Business Ethics,98,99-119

Ehrgott M., Reimann F., Kaufmann L. Carter C.R. (2013) Environmental Development of Emerging Economy Suppliers: Antecedents and Outcomes. Journal of Business Logistics, 34 (2), 131-147

Esper, T. \& Crook, T. R. (2014). Supply chain resources: Advancing theoretical foundations and constructs. Journal of Supply Chain Management, 50(3): 3-5.

Ethiraj, S., Kale, P., Krishnan, M., \& Singh, J. (2005). Where do capabilities come from and how do they matter? A study in the software service industry. Strategic Management Journal, 26(1), 25-45. 
Federations of Indian Chambers of Commerce and Industry. (2014). India-Turkey Trade and Economic Relations Prospects for The Future, A Knowledge Report,http://www.cgiistanbul.org/frontEnd/userfiles/files/IndiaTurkey\%20Trade\%20 and\%20Economic\%20Relations(1).pdf, Accessed September 28, 2015.

Ford, I.D., Hakansson, H., \&Johanson, J. (1986). How do Companies Interact? Industrial Marketing and Purchasing, 1(1), 26-41.

Ford, D., Gadde, L. E., Hakansson, H., \&Snehota, I. (2003). Managing Business Relationships. John Wiley, Chichester.

Foss, N. J. (1999). Networks, capabilities and competitive advantage. Scandinavian Journal of Management, 15(1), 1-16.

Gadde, Lars. E., \&Hakansson, H. (2002). Supply Network Strategies. John Wiley \& Sons LTD, Chichester.

Gaski, J. F. (1984). The Theory of Power and Conflict in Channels of Distribution.Journal of Marketing, 48(2), 9-29.

Gummesson, E. (1994) Making Relationship Marketing Operational, International Journal of Service Industry Management, 5 (5), 5-20.

Hague, J., Oxborrow, L., \&McAtamney, L. (2001). Musculoskeletal disorders and work organisation in the European clothing industry. European Trade Union Technical Bureau for Health and Safety. Belgium.

Hakansson, H. (1982). International Marketing and Purchasing of Industrial Goods. John Wiley \& Sons, Chichester.

Hakansson, H., \& Gadde, L-E. (1992). Supplier relations, Professional Purchasing. Routledge: London.

Hakansson, H., \&Snehota, I. (1995). Developing relationships in business networks. Thomson: London. 
Hakansson, H., \& Waluszewski, A.(2013). A never-ending story: Interaction patterns and economic development. Industrial Marketing Management, 42(3), 443-454.

Halinen, A., \& Törnroos, J.-Å. (2005). Using case methods in the study of contemporary business networks. Journal of Business Research, 58, 1285-1297.

Harrison, D. (2004). Is a Long-Term Relationship an Implied Contract? Two Views of Relationship Disengagement. Journal of Management Studies,41(1), 107-125.

Hines, T., \&McGovan, P. (2005). Supply Chain Strategies in The UK Fashion Industry-The Rhetoric of Partnership and Realities of Power. International Entrepreneurship and Management Journal, 1(4), 519-537.

Hingley, M. K. (2005). Power to all our friends? Living with imbalance in supplier retailer Relationships. Industrial Marketing Management,34(8), 848-858.

Hingley, M., Angell, R., \& Lindgreen, A. (2015). The current situation and future conceptualization of power in industrial markets. Industrial Marketing Management, 48(1), 226-230.

Holmlund, M. (2004). Analyzing business relationships and distinguishing different interaction levels. Industrial Marketing Management, 33(4), 279- 287.

Ireland, R. D., \& Webb, J.W. (2007). Strategic entrepreneurship: creating competitive advantage through streams of innovation. Business Horizons, 50: 49-59.

Johnsen, R.E., \& Ford, D. (2001). Developing the concept of asymmetrical and symmetrical relationships: linking relationship characteristics and firms' capabilities. 18th Annual IMP Conference Proceedings, September 5th-7th, ESC, Dijon, France.

Johnsen, R. E., \& Ford, D. (2006). Interaction capability development of smaller suppliers in relationships with larger customers. Industrial Marketing Management, 35(8),10021015. 
Johnsen, R.E., \& Ford, D. (2008). Exploring the concept of asymmetry: a typology for analysing customer-supplier relationships. Industrial Marketing Management, 37(4), $471-483$.

Johnsen, T. (2009). Supplier involvement in new product development and innovation: Taking stock and looking to the future. Journal of Purchasing and Supply Management, 15(3), 187-197.

Ketchen, Jr D. J., Tomas G., Hult, M. (2007). Bridging organization theory and supply chain management: The case of best value supply chains. Journal of Operations Management, 25, 573-580

Kumar, N. (2005). The power of power in supplier-retailer relationships. Industrial Marketing Management, 34(8), 863-866.

Lacoste, S., \& Johnsen, R. (2015). Supplier-customer relationships: A case study of power dynamics. Journal of Purchasing \& Supply Management, 21(4), 229-240.

Lawler, E.J., Ford, R. S., \& Blegen, M.A. (1988). Coercive capability in conflict: A test of bilateral deterrence versus conflict spiral theory. Social Psychology Quarterly, 51 (2), 93-107.

Lee, C. J., \&Johnsen, R. (2012). Asymmetric customer-supplier relationships in Taiwanese electronics firms. Industrial Marketing Management, 41(4), 692-705.

Leonard-Barton, D. (1992). Core capabilities and core rigidities: a paradox in managing new product development. Strategic Management Journal, 13(4), 111-125.

Lowson, R., 2003, The nature of an operations strategy: combining strategic decisions from the resource-based and market-driven viewpoints, Management Decision, vol. 41 (6) $538-549$ 
Maglaras, G., Bourlakis, M., \& Fotopoulos, C. (2015).Power-imbalanced relationships in the dyadic food chain: An empirical investigation of retailers' commercial practices with suppliers. Industrial Marketing Management, 48, 187-201.

Mattsson, L.G. (1997). Relationship marketing and the markets-as-networks approach- A comparative analysis of two evolving streams of research, in: Journal of Marketing Management, 13, (5), 447-461.

Meehan, J., \& Wright, Gillian, H. (2012). The origins of power in buyer-seller relationships. Industrial Marketing Management, 41(1), 669-679.

Moreira, A. (2009). Knowledge capability flows in buyer-supplier relationships. Challenges for small domestic suppliers in international contexts. Journal of Small Business and Enterprise Development, 16 (1), 93-114.

Miles, M. B., \& Huberman, A. M. (1994). Qualitative data analysis: An expanded sourcebook. London: Sage.

Mintzberg, H., \& Quinn, J.B. (1992). The Strategy Process: Concepts and Contexts. Englewood Cliffs, Prentice Hall.

Munskgaard, K. B., Johnsen, R. E., \& Patterson, C. M. (2015) Knowing me, knowing you: Self- and collective interests in goal development in asymmetric relationships. Industrial Marketing Management, 48(1),160-173.

Nguyi, I, K., Johnsen, R., \& Erdelyi, P. (2010). Relational capabilities for value co-creation and innovation in SMEs. Journal of Small Business and Enterprise Development, 17 (2), 260-278.

Nonaka, I., \& Takeuchi, H. (1995). The knowledge-creating company. New York: Oxford University Press. 
Nyaga, Gilbert N., Lynch, Daniel, F., \& Marshal, D., Ambrose, E. (2013). Power Asymmetry, Adaptation and Collaboration in Dyadic Relationships Involving A Powerful Partner. Journal of Supply Chain Management, 49 (3), 42-65.

Olson, E.M., Slater, S.F., \& Hult, G.T.M., (2005). The performance implications of fit among business strategy, marketing organization structure, and strategic behaviour. Journal of Marketing, 69 (3), 49-65.

Oxborrow, L., \& Brindley, C. (2014). Disintermediation in the apparel supply chain. Journal of Fashion Marketing and Management, 18(30), 252-268.

Prahalad, C.K. \& Hamel, G. (1990). The core competence of the corporation. Harvard Business Review, 68(3), 79-91.

Pulles, Niels J., Veldman, J., Schiele, H., \& Sierksma, H. (2014). Pressure or Pamper? The Effects of Power and Trust Dimensions on Supplier Resource Allocation. Journal of Supply Chain Management, 50(3), 16-36.

Foreign and Commonwealth Office. (2014). Research and Analysis. Turkey: latest killer facts about the economy, https://www.gov.uk/government/publications/turkey-latest-killerfacts-about-the-economy/turkey-latest-killer-facts-about-the-economy, Accessed September 29, 2015.

Ritchie, B., \& Brindley, C. (2000). Disintermediation, disintegration and risk in the SME global supply chain. Management Decision, 38(8), 575 - 583.

Rindt, J., \&Mouzas, S. (2015). Exercising Power in Asymmetric Relationships: the use of private rules. Industrial Marketing Management. 48(1), 202-213.

Sako, M. (1998). Does trust improve business performance? in Lane, C. and Backman, R. (Ed.), Trust within and between organizations: Conceptual issues and empirical application, (pp. 88-117). Oxford: Oxford University Press. 
Sirmon, D. G., Hitt, M. A., Ireland, R. D., \& Gilbert, B. A. (2011). Resource orchestration to create competitive advantage: Breadth, depth, and life cycle management. Journal of Management, 37, 1390-1412.

Stratton, R., \& Warburton, R.D.H. (2006). Managing the trade-off implications of global supply. International Journal of Production Economics, 103 (2), 667-679.

Terpent, R., \& Ashenbaum, B. (2012). The intersection of power: Trust and Supplier Network Size: Implications for Supplier Performance. Journal of Supply Chain Management, 48(3), 52-77.

Teece, D. J. (1998). Capturing value from knowledge assets: The new economy, markets for know-how and intangible assets. California Management Review, 40(3), 55-79.

Tokatli, N. (2006). Asymmetrical power relations and upgrading among suppliers of global clothing brands: Hugo Boss in Turkey. Journal of Economic Geography,7(1), 1-26.

Tokatli, N., \& Kizilgün, O. (2009). From manufacturing garments for ready-to-wear to designing collections for fast fashion: evidence from Turkey. Environment and Planning, 41(1), 146-162.

Tu, C. (2010). Balancing exploration and exploitation capabilities in high technology firms: a multi-source multi-context examination. Industrial Marketing Management, 39 (4), 672-680.

van Hoek, R. I. (2000). Role of third party logistic services in customization through postponement. International Journal of Service Industry Management, 11(4), 374 - 387.

Webb, J. W., Tihanyi, L., Ireland, R. D., \& Sirmon, D. G. 2009. You say illegal, I say legitimate: Entrepreneurship in the informal economy. Academy of Management Review, 34: 492-510. 
Wowak, K. D., Craighead, C, W., Ketchen JR, D.J., \& Hult, G.T.M. (2015). Toward a "theoretical toolbox" for the supplier-enabled fuzzy front end of the new product development process. Journal of Supply Chain Management, 0(0), 1-16.

Yin, R.K. (2003). Case study research: design and methods. Sage, London. 
Table 2: Case Companies' Capability Sets

\begin{tabular}{|c|c|c|c|c|c|}
\hline $\begin{array}{l}\text { Case } \\
\text { Companies }\end{array}$ & Employee Capability & $\begin{array}{l}\text { Technical } \\
\text { Capability }\end{array}$ & $\begin{array}{l}\text { Managerial } \\
\text { Capability }\end{array}$ & $\begin{array}{l}\text { Custom } \\
\text { Capability }\end{array}$ & Overcoming Power Asymmetry \\
\hline $\begin{array}{l}\text { Case A } \\
\text { (213):man } \\
\text { ufacturer } \\
\text { of formal } \\
\text { clothes }\end{array}$ & $\begin{array}{l}\text { - Up-to-date } \\
\text { production } \\
\text { knowledge gained } \\
\text { from machine } \\
\text { suppliers and } \\
\text { horizontal } \\
\text { relationships. } \\
\text { - Customer } \\
\text { relationship } \\
\text { management }\end{array}$ & $\begin{array}{l}\text { - R\&D focused, with } \\
\text { efficient production, } \\
\text { embroidery and } \\
\text { sewing techniques } \\
\text { - Technical translation } \\
\text { of customer needs } \\
\text { for production. }\end{array}$ & $\begin{array}{l}\text { - Structured } \\
\text { management system } \\
\text { and performance } \\
\text { measurement. } \\
\text { - Skills matching and } \\
\text { stress management. }\end{array}$ & $\begin{array}{l}\text { - } \text { Timely customer } \\
\text { service with } \\
\text { relationships at } \\
\text { operational and } \\
\text { management level. } \\
\text { - Tailored response to } \\
\text { customer needs and } \\
\text { identity }\end{array}$ & $\begin{array}{l}\text { - } \text { Personal ties and } \\
\text { collaboration for third-party } \\
\text { supplier choice } \\
\text { - Having relationships with } \\
\text { distinct export market } \\
\text { customers } \\
\text { - Existing Technology and } \\
\text { Experience } \\
\text { - Distinct market customers } \\
\text { - Individual involvement (top } \\
\text { management) } \\
\text { - Personal relations and local } \\
\text { knowledge }\end{array}$ \\
\hline $\begin{array}{l}\text { Case B } \\
\text { (33):design } \\
\text { and in- } \\
\text { house } \\
\text { manufactu } \\
\text { rer of } \\
\text { leisure } \\
\text { wear }\end{array}$ & $\begin{array}{l}\text { - } \text { Market dynamics and } \\
\text { trends } \\
\text { - Raw material } \\
\text { purchasing } \\
\text { - Buyer relationships }\end{array}$ & $\begin{array}{l}\text { - Advanced flexible } \\
\text { manufacturing } \\
\text { technology } \\
\text { - Fibre / textile trim } \\
\text { technologies }\end{array}$ & $\begin{array}{l}\text { - Short-term/ } \\
\text { operational decisions } \\
\text { orientation } \\
\text { - Effective production } \\
\text { management }\end{array}$ & $\begin{array}{lr}\text { - Strong r personal } \\
\text { influence } \\
\text { company } \\
\text { - Need } \\
\text { customer interactions } \\
\text { and understanding }\end{array}$ & $\begin{array}{l}\text { - Employee experience and } \\
\text { local knowledge } \\
\text { - Increasing personal } \\
\text { relationships with customers. } \\
\text { - Technical experience }\end{array}$ \\
\hline $\begin{array}{l}\text { Case C } \\
\text { (21):design } \\
\text { and in- } \\
\text { house } \\
\text { manufactu } \\
\text { rer of } \\
\text { formal } \\
\text { clothes }\end{array}$ & $\begin{array}{l}\text { - IT systems and } \\
\text { manufacturing. } \\
\text { - Foreign language } \\
\text { - Lacking customer } \\
\text { development and } \\
\text { communication and } \\
\text { international vision. }\end{array}$ & $\begin{array}{l}\text { - INCOTERMS. } \\
\text { - Production } \\
\text { technology and } \\
\text { quality } \\
\text { - design process. }\end{array}$ & $\begin{array}{l}\text { - In-house focus with } \\
\text { lack of leadership and } \\
\text { customer relationship } \\
\text { management. } \\
\text { - Emphasising } \\
\text { personal involvement } \\
\text { in customer }\end{array}$ & $\begin{array}{l}\text { - Building high quality } \\
\text { standards and } \\
\text { motivating staff } \\
\text { - Limited } \\
\text { understanding of } \\
\text { customers / markets }\end{array}$ & 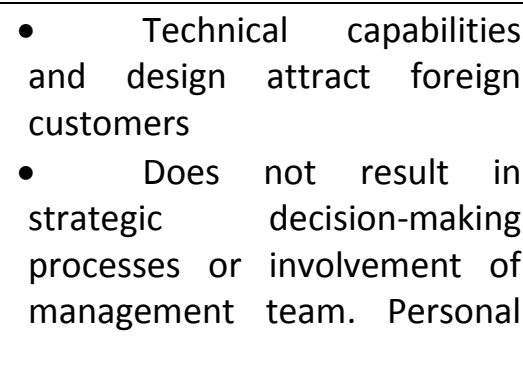 \\
\hline
\end{tabular}




\begin{tabular}{|c|c|c|c|c|c|}
\hline & & & $\begin{array}{l}\text { relationship } \\
\text { management } \mathrm{t} .\end{array}$ & & relations are most effective. \\
\hline $\begin{array}{l}\text { Case D } \\
(240): \text { in- } \\
\text { house } \\
\text { manufactu } \\
\text { rer of } \\
\text { leisure } \\
\text { wear }\end{array}$ & $\begin{array}{l}\text { - Technical translation } \\
\text { of customer orders } \\
\text { - Garment production; } \\
\text { raw materials and } \\
\text { textiles. }\end{array}$ & 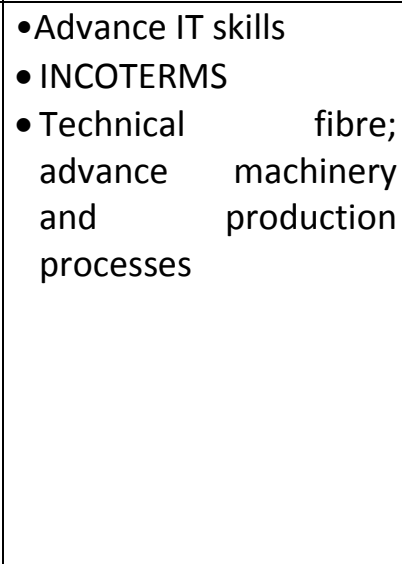 & $\begin{array}{l}\text {-Advanced customer- } \\
\text { relationship } \\
\text { management and } \\
\text { inter-company } \\
\text { interactions } \\
\text { - Production process } \\
\text { driven }\end{array}$ & $\begin{array}{l}\text { - Understanding of } \\
\text { customer } \\
\text { expectations and } \\
\text { cultural differences } \\
\text { - Need to understand } \\
\text { customer better }\end{array}$ & $\begin{array}{l}\text { - Developed and improved } \\
\text { technological capabilities with } \\
\text { new focus on tailored } \\
\text { production, involving staff } \\
\text { and joint projects. } \\
\text { - Top management understand } \\
\text { customer expectations and } \\
\text { Italian customer relationships } \\
\text { are institutionalised; frequent } \\
\text { communication and } \\
\text { information-sharing solve } \\
\text { problems. }\end{array}$ \\
\hline $\begin{array}{l}\text { Case E } \\
\text { (38):design } \\
\text { and in- } \\
\text { house } \\
\text { manufactu } \\
\text { rer of } \\
\text { uniform }\end{array}$ & $\begin{array}{l}\text { - Fibre and textile raw } \\
\text { material } \\
\text { - Export procedure and } \\
\text { foreign language } \\
\text { - Manufacturing } \\
\text { processes }\end{array}$ & $\begin{array}{l}\text { - } \text { Advanced technical } \\
\text { machinery and } \\
\text { flexible production } \\
\text { techniques } \\
\text { - Tailor-made } \\
\text { production / designs } \\
\text { - Computer-aided } \\
\text { customer tracking }\end{array}$ & $\begin{array}{l}\text { - Employee } \\
\text { management } \\
\text { - Customer and } \\
\text { Supplier relationship } \\
\text { management }\end{array}$ & $\begin{array}{l}\text { - Cross-cultural and } \\
\text { international } \\
\text { interaction } \\
\text { - Customer } \\
\text { expectations } \\
\text { managed via frequent } \\
\text { visits and } \\
\text { communication }\end{array}$ & $\begin{array}{l}\text { - Technological capabilities } \\
\text { maintain relationships with } \\
\text { current customers but lack } \\
\text { future vision. } \\
\text { - Proactive relationship } \\
\text { investment maintains } \\
\text { relationships and solves } \\
\text { problems, but is not } \\
\text { developing advanced } \\
\text { opportunities. }\end{array}$ \\
\hline $\begin{array}{l}\text { Case } \\
F(\mathbf{1 0 0}) \text { : } \\
\text { manufactu } \\
\text { rer of } \\
\text { formal } \\
\text { wear }\end{array}$ & $\begin{array}{l}\text { - Production process } \\
\text { and design } \\
\text { - Risk management } \\
\text { and avoidance } \\
\text { - Export procedures }\end{array}$ & $\begin{array}{l}\text { - Advanced fast } \\
\text { production skills and } \\
\text { in-house production } \\
\text { systems }\end{array}$ & $\begin{array}{l}\text { - Customer quality } \\
\text { drivers } \\
\text { - Managing flexible } \\
\text { production processes } \\
\text { - Short-term decision } \\
\text { maker }\end{array}$ & $\begin{array}{l}\text { - Strong individual } \\
\text { beliefs and norms } \\
\text { - Risk-averse with } \\
\text { foreign customers; } \\
\text { formal contract driven } \\
\text { - Awareness of } \\
\text { changing customer } \\
\text { trends }\end{array}$ & $\begin{array}{l}\text { - } \text { Developed production } \\
\text { capabilities and facilities; } \\
\text { technical capability maintains } \\
\text { relationships and supports } \\
\text { co-operation rather than } \\
\text { conflict. } \\
\text { - Managerial capabilities are } \\
\text { strategic, not based on day- } \\
\text { to-day decisions. Tight }\end{array}$ \\
\hline
\end{tabular}




\begin{tabular}{|c|c|c|c|c|c|}
\hline & & & & & internal systems and control. \\
\hline $\begin{array}{l}\text { Case } \\
\text { G (111): } \\
\text { design and } \\
\text { in-house } \\
\text { manufactu } \\
\text { rer of work } \\
\text { wear }\end{array}$ & $\begin{array}{l}\text { - Production process } \\
\text { and manufacturing } \\
\text { - Range of materials }\end{array}$ & $\begin{array}{l}\text { - Translating customer } \\
\text { orders into } \\
\text { production } \\
\text { - Chemical laboratory } \\
\text { equipment and } \\
\text { applications }\end{array}$ & $\begin{array}{l}\text { - } \text { Management } \\
\text { systems for } \\
\text { manufacturing and } \\
\text { customer- } \\
\text { relationship } \\
\text { management } \\
\text { - Integrated } \\
\text { laboratory and } \\
\text { manufacturing }\end{array}$ & $\begin{array}{l}\text { - Niche market } \\
\text { products advantages. } \\
\text { - Company culture } \\
\text { dominates } \\
\text { relationships. }\end{array}$ & $\begin{array}{l}\text { - Long-term relationships with } \\
\text { customers with regular orders } \\
\text { and communications. } \\
\text { - Strengths in technical-based } \\
\text { interactions with customers. }\end{array}$ \\
\hline $\begin{array}{l}\text { Case H } \\
\text { (127):man } \\
\text { ufacturer } \\
\text { of kids } \\
\text { wear }\end{array}$ & $\begin{array}{l}\text { - Production processes } \\
\text { and manufacturing, } \\
\text { technologies and } \\
\text { design } \\
\text { - Collaborative } \\
\text { approach to sort } \\
\text { problems within } \\
\text { company. }\end{array}$ & $\begin{array}{l}\text { - Translating technical } \\
\text { documents into } \\
\text { production. } \\
\text { - Aspires to high } \\
\text { quality production. } \\
\text { - Organic fibres and } \\
\text { processes and R\&D }\end{array}$ & $\begin{array}{l}\text { - Key customer } \\
\text { management skills } \\
\text { - Team- oriented with } \\
\text { quality / training } \\
\text { focus. } \\
\text { - Tensions between } \\
\text { customers and } \\
\text { production } \\
\text { department. }\end{array}$ & $\begin{array}{l}\text { - Clear understanding } \\
\text { of foreign cultures, } \\
\text { organisational } \\
\text { routines and } \\
\text { communication. } \\
\text { - R\&D and innovation- } \\
\text { oriented. }\end{array}$ & $\begin{array}{l}\text { - Technological advancement } \\
\text { and continuous R\&D supports } \\
\text { relationships, attracts export } \\
\text { buyers, and solutions for } \\
\text { problems without } \\
\text { dependency on customers. } \\
\text { - Management team is well } \\
\text { resourced. }\end{array}$ \\
\hline $\begin{array}{l}\text { Case I (24): } \\
\text { design and } \\
\text { in house } \\
\text { manufactu } \\
\text { rer of } \\
\text { lingerie }\end{array}$ & $\begin{array}{l}\text { - Fibre and textiles } \\
\text { - Production processes } \\
\text { - Negotiation } \\
\text { techniques and } \\
\text { foreign language }\end{array}$ & $\begin{array}{l}\text { - Flexible and fast } \\
\text { production and cost- } \\
\text { efficient techniques } \\
\text { - Computer-aided } \\
\text { customer tracking } \\
\text { system. }\end{array}$ & $\begin{array}{l}\text { - Tight control over } \\
\text { manufacturing and } \\
\text { human resources } \\
\text { - Personal customer } \\
\text { relationships and } \\
\text { problem solving }\end{array}$ & $\begin{array}{l}\text { - Customer } \\
\text { expectations; ethics; } \\
\text { and evaluation of } \\
\text { different export } \\
\text { markets. }\end{array}$ & $\begin{array}{l}\text { - Technological and production } \\
\text { orientated, not customer- } \\
\text { driven; }\end{array}$ \\
\hline $\begin{array}{l}\text { Case J (35): } \\
\text { design and } \\
\text { in-house } \\
\text { manufactu } \\
\text { rer of }\end{array}$ & $\begin{array}{l}\text { - Knitting applications } \\
\text { and machinery } \\
\text { - Customer needs } \\
\text { translated into } \\
\text { production processes }\end{array}$ & $\begin{array}{l}\text { - Faste, flexible and } \\
\text { cost- } \\
\text { efficientproduction } \\
\text { techniques } \\
\text { - Translate technical }\end{array}$ & $\begin{array}{l}\text { - Manufacturing } \\
\text { management } \\
\text { Proactive planning } \\
\text { to avoid market } \\
\text { uncertainties }\end{array}$ & $\begin{array}{l}\text { - Exclusive services } \\
\text { - Understanding } \\
\text { customer } \\
\text { expectations } \\
\text { - Differentiating }\end{array}$ & $\begin{array}{l}\text { - Managerial capabilities } \\
\text { support strategic decision } \\
\text { making withcustomersand } \\
\text { communication. } \\
\text { - Manufacturing innovation }\end{array}$ \\
\hline
\end{tabular}




\begin{tabular}{|c|c|c|c|c|c|}
\hline $\begin{array}{l}\text { sports } \\
\text { wear }\end{array}$ & $\begin{array}{l}\text { - Understand market } \\
\text { conditions issues }\end{array}$ & $\begin{array}{l}\text { details } \\
\text { production }\end{array}$ & & $\begin{array}{l}\text { customers' cultural } \\
\text { values and ethics }\end{array}$ & $\begin{array}{l}\text { supports customer } \\
\text { cooperation in product } \\
\text { development/ design. }\end{array}$ \\
\hline $\begin{array}{l}\text { Case } \mathbf{K}(30) \\
\text { Ladies fast } \\
\text { fashion } \\
\text { manufactu } \\
\text { re }\end{array}$ & $\begin{array}{l}\text { - Focus on developing } \\
\text { hard-to-find } \\
\text { production skills }\end{array}$ & $\begin{array}{l}\text { - Building capacity for } \\
\text { fast and flexible } \\
\text { production. } \\
\text { - Order processes } \\
\text { dominate nature of } \\
\text { relationships. }\end{array}$ & $\begin{array}{l}\text { - Experienced former } \\
\text { buyer with } \\
\text { established external } \\
\text { networks. Formal } \\
\text { management } \\
\text { structure. } \\
\text { - Understands } \\
\text { customer } \\
\text { expectations. }\end{array}$ & $\begin{array}{l}\text { - Exploit knowledge of } \\
\text { buyers and internal } \\
\text { competition within } \\
\text { buying departments. } \\
\text { - Customers are } \\
\text { compliance driven, as } \\
\text { well as cost. }\end{array}$ & $\begin{array}{l}\text { - Manage customer } \\
\text { expectations to secure win- } \\
\text { win. Need to stand ground } \\
\text { and say no. } \\
\text { - Strength in fast turnaround } \\
\text { with quality and compliance - } \\
\text { but this comes at a cost to } \\
\text { business. }\end{array}$ \\
\hline $\begin{array}{l}\text { Case L(32) } \\
\text { Design and } \\
\text { distribute } \\
\text { branded } \\
\text { hosiery }\end{array}$ & $\begin{array}{l}\text { - Technical product. } \\
\text { Hard to source. Offer } \\
\text { design of hosiery and } \\
\text { packaging } \\
\text { - In-house } \\
\text { merchandisers } \\
\text { manage inventory } \\
\text { and allocation to } \\
\text { maximise availability }\end{array}$ & $\begin{array}{l}\text { - No local } \\
\text { infrastructure } \\
\text { remaining. Lack } \\
\text { investment in UK } \\
\text { manufacture. } \\
\text { - Manage upstream } \\
\text { sourcing. }\end{array}$ & $\begin{array}{l}\text { - Pro-active risk } \\
\text { management } \\
\text { towards order } \\
\text { management and } \\
\text { inventory. } \\
\text { - Production } \\
\text { management skills } \\
\text { replaced by complex } \\
\text { sourcing } \\
\text { management. }\end{array}$ & $\begin{array}{l}\text { - Tension with } \\
\text { customers over order } \\
\text { processes, cost focus } \\
\text { and delays. } \\
\text { - Supplier in China } \\
\text { becoming more } \\
\text { powerful creating } \\
\text { pressure at both ends } \\
\text { of supply chain. }\end{array}$ & $\begin{array}{l}\text { - Design and quality driven. } \\
\text { - Managed risk helps maximise } \\
\text { sales and reduce markdowns, } \\
\text { supporting customer } \\
\text { relationships. } \\
\text { - Brand options hedge against } \\
\text { risk, while outsourced } \\
\text { production gives flexibility in } \\
\text { product, price and lead time. }\end{array}$ \\
\hline $\begin{array}{l}\text { Case } \\
\mathbf{M}(<10) \\
\text { Sale agent } \\
\text { representi } \\
\text { ng ladies' } \\
\text { wear } \\
\text { manufactu } \\
\text { rer }\end{array}$ & $\begin{array}{l}\text { - Flexibility limited by } \\
\text { global structure - } \\
\text { imports for } \\
\text { customers. } \\
\text { - Buying offices in India } \\
\text { and China to manage } \\
\text { supplier activities. } \\
\text { - Key account manager } \\
\text { system for each } \\
\text { buyer }\end{array}$ & $\begin{array}{l}\text { - No design - customer } \\
\text { design pack provided } \\
\text { to test price and } \\
\text { specification. } \\
\text { - Excessive sampling at } \\
\text { customer request. }\end{array}$ & $\begin{array}{l}\text { - Experienced manager } \\
\text { is ex-buyer. } \\
\text { - Pro-active customer } \\
\text { relationship building } \\
\text { leads to shared } \\
\text { forecasts. }\end{array}$ & $\begin{array}{l}\text { - Lacks management } \\
\text { control } \\
\text { - Key account } \\
\text { management based } \\
\text { on gender and } \\
\text { culture. } \\
\text { - Focused on building } \\
\text { trust to overcome } \\
\text { 'fear' of unscrupulous } \\
\text { buyers. }\end{array}$ & $\begin{array}{l}\text { - Proactive customer } \\
\text { relationship management to } \\
\text { win more business and } \\
\text { develop trustworthiness } \\
\text { - Asian suppliers gaining power } \\
\text { so upstream relationships are } \\
\text { equally asymmetrical. }\end{array}$ \\
\hline
\end{tabular}




\begin{tabular}{|c|c|c|c|c|c|}
\hline $\begin{array}{l}\text { Case } \\
\mathbf{N}(180) \\
\text { Jeans } \\
\text { manufactu } \\
\text { re: UK/ } \\
\text { Morocco } \\
\end{array}$ & $\begin{array}{l}\text { - } \text { Creative and } \\
\text { innovative. } \\
\text { - } \text { Customer cost } \\
\text { driven. Production/ } \\
\text { technical skills } \\
\text { shortage }\end{array}$ & $\begin{array}{l}\text { - New factory in UK. } \\
\text { - Lacks responsiveness. } \\
\text { Customer cost drivers } \\
\text { inhibit innovation. } \\
\text { - Accreditationburden. }\end{array}$ & $\begin{array}{l}\text { - Pro-active risk } \\
\text { management of } \\
\text { ordering / inventory. } \\
\text { - Sourcing options for } \\
\text { different retailers. }\end{array}$ & $\begin{array}{l}\text { - Cost is key } \\
\text { management driver. } \\
\text { - Survival of the fittest. }\end{array}$ & $\begin{array}{l}\text { - Supply higher value product } \\
\text { to increase margins. } \\
\text { - Manage risk with flexible UK } \\
\text { capacity and range of } \\
\text { compliant sourcing options. }\end{array}$ \\
\hline $\begin{array}{l}\text { Case } \mathbf{O}(6) \\
\text { Small } \\
\text { children } \\
\text { swear/ } \\
\text { womensw } \\
\text { ear }\end{array}$ & 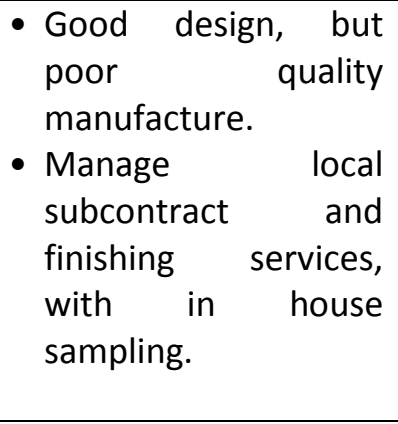 & $\begin{array}{l}\text { - Design process } \\
\text { involves customer, } \\
\text { but adds to cost. } \\
\text { - CAD capability } \\
\text { unused due to } \\
\text { resource cost. } \\
\text { - Low cost attracts } \\
\text { repeat orders. }\end{array}$ & $\begin{array}{l}\text { - Owner manages } \\
\text { relationships with } \\
\text { suppliers; designer } \\
\text { and owner with } \\
\text { customers. } \\
\text { - Internal } \\
\text { communications } \\
\text { inadequate. }\end{array}$ & $\begin{array}{l}\text { - Use non-compliant } \\
\text { factories. } \\
\text { - Upstream services } \\
\text { owned by relatives - } \\
\text { aids cash flow. } \\
\text { - Designer experienced } \\
\text { in large company } \\
\text { with formal } \\
\text { relationships. } \\
\end{array}$ & $\begin{array}{l}\text { - Selling points are fast } \\
\text { turnaround and low prices, } \\
\text { rather than ethics or quality. } \\
\text { - Business is growing rapidly. } \\
\text { - Attempts to involve retailer in } \\
\text { design not readily accepted, } \\
\text { relationship lacks trust. }\end{array}$ \\
\hline $\begin{array}{l}\text { Case } \\
\mathbf{P}(90+60) \\
\text { Supplier } \\
\text { and } \\
\text { Manufactu } \\
\text { rer }\end{array}$ & $\begin{array}{l}\text { - Strong design and } \\
\text { technical skills. } \\
\text { Owned } \\
\text { manufacturing } \\
\text { company has } \\
\text { production skills. } \\
\text { - Tension due to lack } \\
\text { of skills in buying } \\
\text { teams. }\end{array}$ & $\begin{array}{l}\text { - Technical skills } \\
\text { overlooked by buyer } \\
\text { - creates tension. } \\
\text { - Negotiation with } \\
\text { customer helps } \\
\text { identify solutions to } \\
\text { garment technical } \\
\text { issues. }\end{array}$ & $\begin{array}{l}\text { - Formal structure. } \\
\text { Company organised } \\
\text { as manufacturer and } \\
\text { design/agent, } \\
\text { providing sourcing } \\
\text { and sales services. } \\
\text { Each has its own } \\
\text { management and } \\
\text { technical team. }\end{array}$ & $\begin{array}{l}\text { - } \text { Cost is dominant } \\
\text { issue in relationships. } \\
\text { - Favour ethical } \\
\text { working conditions. } \\
\text { Competence and } \\
\text { management } \\
\text { strength support } \\
\text { relationships. }\end{array}$ & $\begin{array}{l}\text { - } \text { Attempts to re-educate } \\
\text { buying teams helps } \\
\text { relationships. } \\
\text { - Balance: cost, quality, } \\
\text { fashion. } \\
\text { - Quality and ethical stance are } \\
\text { differentiating factors. } \\
\text { - Sourcing options matched to } \\
\text { customer needs. }\end{array}$ \\
\hline $\begin{array}{l}\text { Case Q(15) } \\
\text { Fast } \\
\text { fashion } \\
\text { womensw } \\
\text { ear }\end{array}$ & $\begin{array}{l}\text { - Sourcing, import \& } \\
\text { technical expertise. } \\
\text { - Freelance } \\
\text { designerprovidescust } \\
\text { omer liaison. } \\
\text { - Owner manages } \\
\text { upstream supply } \\
\text { chain, including 'own' } \\
\text { factory in N. Africa. }\end{array}$ & $\begin{array}{l}\text { - Integrated internet } \\
\text { communication with } \\
\text { customers and some } \\
\text { suppliers. Liaise } \\
\text { upstream with } \\
\text { suppliers in Far East/ } \\
\text { Eastern Europe. }\end{array}$ & $\begin{array}{l}\text { - Developing } \\
\text { relationship with new } \\
\text { retailer - samples } \\
\text { copied; confrontation } \\
\text { resolved in court. }\end{array}$ & $\begin{array}{l}\text { - Asian business. Key } \\
\text { account management } \\
\text { on grounds of genre } \\
\text { and race; but self- } \\
\text { employed. }\end{array}$ & $\begin{array}{l}\text { - Bought in customer liaison } \\
\text { function in freelance } \\
\text { designer. } \\
\text { - On/off relationship - go extra } \\
\text { mile to win business. } \\
\text { - Negotiation difficult to } \\
\text { resolve and company at risk } \\
\text { of losing business. }\end{array}$ \\
\hline
\end{tabular}




\begin{tabular}{|c|c|c|c|c|c|}
\hline $\begin{array}{l}\text { Case } \mathbf{R}(15) \\
\text { fashion } \\
\text { knitwear }\end{array}$ & $\begin{array}{l}\text { Developing market } \\
\text { for product of new } \\
\text { knit technology; } \\
\text { - Sampling reduced by } \\
\text { CAD }\end{array}$ & $\begin{array}{l}\text { - Upstream ownership } \\
\text { by yarn supplier } \\
\text { provides some } \\
\text { materials advantage; } \\
\text { - Relationships: high } \\
\text { street retailers treat } \\
\text { as 'trial supplier'. }\end{array}$ & $\begin{array}{l}\text { - Didn't appreciate } \\
\text { contract terms for } \\
\text { new retailer. } \\
\text { - Goods delivered into } \\
\text { chain store } \\
\text { distribution centre on } \\
\text { time, but paid for as } \\
\text { 'called-off'. Affects } \\
\text { cashflow. }\end{array}$ & $\begin{array}{l}\text { - Vertically integrated } \\
\text { owned by yarn } \\
\text { supplier. } \\
\text { - Asian family business. } \\
\text { Parent company } \\
\text { employs professional } \\
\text { white male sales } \\
\text { representative. }\end{array}$ & $\begin{array}{l}\text { - Technical expertise } \\
\text { - Account management } \\
\text { culturally matched to buyer } \\
\text { - Family finance from upstream } \\
\text { company. } \\
\text { - Need to develop } \\
\text { management capability to } \\
\text { meet customer expectations } \\
\text { and mitigate risks. }\end{array}$ \\
\hline $\begin{array}{l}\text { Case S (15) } \\
\text { Knitwear } \\
\text { for mid- } \\
\text { market } \\
\text { mature } \\
\text { customer. }\end{array}$ & $\begin{array}{l}\text { - Dependent on direct } \\
\text { sales to smaller, low } \\
\text { value retail chains } \\
\text { aimed at mature } \\
\text { consumer. } \\
\text { - Other companies } \\
\text { serve similar market } \\
\text { with same level of } \\
\text { flexibility. }\end{array}$ & $\begin{array}{l}\text { Low tech, design } \\
\text { based on sampling } \\
\text { and knitted swatch } \\
\text { for wholesale and } \\
\text { mid-size retail chains. }\end{array}$ & $\begin{array}{l}\text { - Two designers } \\
\text { 'manage' owner. } \\
\text { Professional first } \\
\text { impressions, more } \\
\text { polished than most } \\
\text { ethnic SMEs. }\end{array}$ & $\begin{array}{l}\text { Designer 'Head- } \\
\text { hunted' from } \\
\text { relative's knit } \\
\text { company - move has } \\
\text { caused a family rift. } \\
\text { Ethnic owned } \\
\text { business with white } \\
\text { female designer. }\end{array}$ & $\begin{array}{l}\text { - Account management } \\
\text { culturally matched to buyer } \\
\text { - Niche market shows that this } \\
\text { relationship is less } \\
\text { asymmetric than others. } \\
\text { - Need to provide new } \\
\text { markets. }\end{array}$ \\
\hline $\begin{array}{l}\text { Case T } \\
\text { Fast } \\
\text { Fashion } \\
\text { separates } \\
\text { (20) }\end{array}$ & $\begin{array}{l}\text { - Design and sampling } \\
\text { expertise - largely } \\
\text { manual } \\
\text { - Superior cutting and } \\
\text { production } \\
\text { capabilities. } \\
\text { Specialise in } \\
\text { matching checks and } \\
\text { plaid. }\end{array}$ & $\begin{array}{l}\text { - Established } \\
\text { relationships with } \\
\text { high street stores. } \\
\text { Always 'under threat'. } \\
\text { - }\end{array}$ & $\begin{array}{l}\text { Owner manager } \\
\text { spends day each } \\
\text { week travelling to } \\
\text { meet customer face- } \\
\text { to-face. }\end{array}$ & $\begin{array}{l}\text { - Designers who can't } \\
\text { sell and develop } \\
\text { business don't last } \\
\text { long! }\end{array}$ & $\begin{array}{l}\text { - Face to face contact } \\
\text { important and regular. Will fly } \\
\text { desgner to Sweden to meet } \\
\text { retail. } \\
\text { - Niche capability - retailers go } \\
\text { away but come back as } \\
\text { capabilities hard to replace. }\end{array}$ \\
\hline
\end{tabular}

